\title{
Kidnapping Politics in East Asia
}

\author{
Richard J. Samuels
}

In this article, I examine two contemporary cases in which the same foreign adversary, North Korea (DPRK), violated the sovereignty of neighboring states. I use a comparison of South Korean and Japanese reactions to political captivity to assess institutional performance in democratic states and ways in which these dynamics are connected to international politics. We see how "captivity narratives" can be differentially constructed and deployed and how policy capture can be achieved by determined political actors. Civic groups in both countries worked to mobilize political support, frame the issue for the media, and force policy change. In Japan, politicians were more willing to use the abduction issue for domestic political gain than in Korea, where the political class was determined to prevent human rights issues (including abductions) from interfering with their larger political agenda, including improved relations with the DPRK.

KEYwORDS: kidnapping, abduction, captivity, sovereignty, political leadership, civil society, media capture, institutional performance, Japanese foreign policy, South Korean foreign policy

istory is filled with political abductions, incidents in which individuals are kidnapped and held hostage by hostile groups or states to gain leverage or legitimacy for their cause. ${ }^{1}$ Such episodes have been used since antiquity to highlight the failure of rulers to perform their single most important function-protecting citizens from harm. Consequently, kidnappings have opened up deep political chasms and often have been used by political actors to identify enemies, distill collective fears, clarify national deficiencies, redefine frontiers, and mobilize social movements. They have long figured in justifications for both aggression and conciliation with neighbors. Some political actors have capitalized on captivity to frame and highlight national weakness and the fecklessness of leaders. Others have spun out accounts of heroism to demonstrate national strength and visionary leadership. Either way, the manipulation of the captivity passion for po- 
litical ends often has been used to generate public sympathy to reorient national policies.

In this article, I examine two contemporary cases in which the same foreign adversary, North Korea (DPRK), violated the sovereignty of neighboring states. North Korean abductions of Japanese and South Korean (ROK) nationals illuminate how "captivity narratives" can be differentially constructed and deployed; they offer a window on the mechanisms involved in policy capture - the metaphorical analogue to the incident itself.

\section{The Comparison}

Comparing the South Korean and Japanese reactions to political captivity provides a valuable vantage point to assess institutional change in democratic states and ways in which these dynamics are connected to international politics. ${ }^{2}$ Jack Snyder's explanation of how parochial interests can "hijack" foreign policy is particularly helpful in this regard. Building upon a long tradition in comparative politics-including assumptions about state capacity and the distribution of interests-Snyder argues that groups favoring muscular foreign policies often enjoy advantages in "organizational persuasiveness"-motivational advantages, control of information resources, and close ties to the state-that enable them to capture national policy (Snyder 1991, 32; see Olson 1965; Wilson 1980; Gourevitch 1986; Katzenstein 1977). ${ }^{3}$ Groups with expansionist interests, he argues, tend to be more compact and concentrated than their opponents. In a cartelized polity, this provides institutional advantages that enable them to "propagate the myth of security through expansion in the guise of the general interest of society" (Snyder 1991, 31). Armed with a persuasive idea and fortified by cartelized power, they can kidnap politics. Snyder suggests further that the system may become so rigid - either through logrolling or cognitive dissonance - that the actors may misinterpret or ignore information pointing to overextension and end up with policies that harm the very interest groups that promoted them.

The Japan-ROK comparison offers a particularly clear window on one of Snyder's central questions: whether more open democracies are apt to correct for the most extreme excesses (Snyder 1991, 312). Both the Japanese and South Korean political systems shifted between being highly cartelized and relatively more open and competitive. From 1955 to 2009 Japan was governed by what was considered a "one and a half 
party system" under the near hegemonic leadership of the Liberal Democratic Party (LDP). During this same period, South Korea was governed by an authoritarian clique until 1987, when democratic politics were introduced. By the 1990s, both countries had competitive party systems, regular elections, a nominally independent (and ideologically diverse) media, and open civil societies. Captivity in both cases has been a compelling emotional issue, cutting to the heart of debates over how national identity and national interest are defined. In both South Korea and Japan, abductee family groups became particularly active just before and after a summit meeting between their national leaders and Kim Jong Il. Groups in civil society in both countries seized upon the human rights issue and attempted to ally with politicians to confront bureaucrats, manipulate public sentiment, and reorder national policy priorities.

While this comparison does not allow us to hold the international system perfectly constant, the foreign relations of Japan and the ROK also have much in common. Throughout the second half of the twentieth century and until the present, both countries have had the same powerful security partner (the United States) and each has faced an existential threat from the same hostile neighbor (North Korea). The most significant structural discrepancy derives from the difference in Japan-North Korea relations and South Korea-North Korea relations. Unlike the Japanese, South Koreans all serve in the military and-until Pyongyang's nuclear tests-have been exposed to a more direct threat from the North. Abductions, moreover, have been more widespread in South Korea than in Japan. In examining the relevance of these differences, I am struck by one commonality above all others: by failing to prevent repeated violations of their sovereignty by North Korea and by failing to protect their citizens from harm by foreign agents, both states faced severe disapprobation for not performing adequately their most central function in international society.

Despite important common features, however, we observe very different outcomes in South Korea and Japan on the abductee issue. In Japan, the captivity narrative was used to shed harsh light on the discontent and dysfunction of contemporary democratic politics and public policy. The media, the political class, and the bureaucrats all shifted position on one of the most divisive and explosive issues in Japanese foreign and security policy. Emotional appeals married to state failures were used to trump more dispassionate calculations of national interest. There have been few heroic, stalwart leaders in Japan, where the captivity narrative has been dominated by feckless, opportunistic politicians, cowed journalists, inept bureaucrats, and emboldened civic activists on the right. ${ }^{4}$ 
Seoul, however, successfully redirected efforts of similar groups to determine policy toward Pyongyang. Unlike in Japan, where public opinion convulsed into paroxysms of demand making and finger pointing, the South Korean public never rallied to the side of the abductees' families and has not supported the combined efforts of family groups with right-wing nongovernmental organizations (NGOs). Although the majority of South Koreans agreed in 2008 that the prisoner of war (POW)/abductees issue should be resolved in the near future, only a small minority (7 percent) considered this to be the most important issue in North-South dialogue, or even a priority in South-North relations. Indeed, it is near the bottom of a long list in which the nuclear issue (29 percent), military tensions (28 percent), and economic cooperation (16 percent) were far more important. ${ }^{5}$ The relative indifference of the South Korean public should not be surprising, because the terms $P O W$ or abductees were not even mentioned in any obtainable surveys before $2007 .^{6}$

These differences are reflected in policy. In contrast to Japan, where the Liberal Democrats used the abduction issue to craft an unexpected victory in November 2003 and where a separate cabinet office was established on the issue with the prime minister as ex-officio chair, there was only minor policy adjustment on the abductee issue in South Korea. The ROK government long conflated families separated by war with those separated by North Korean agents. It long refused even to use the term abduction, and even after it began to do so, it refused to invoke it in negotiations with the DPRK. The National Assembly did not establish an Abductees Compensation and Assistance Review Committee until April 2007, and the number of abductees and families receiving compensation is very limited. In short, unlike Tokyo, Seoul never allowed its diplomacy to be kidnapped by the abductee issue. It is as if there was no one to write South Korea's captivity narrative.

These differences are all the more curious given South Korea's history of caustic political discourse, general characterizations of Korean public opinion as more volatile than Japanese public opinion, and the fact that the suffering of "separated families" is more widespread in Korea than in Japan. Why was the Japanese state more entangled by a mobilized citizenry than the South Korean state? Why were the less mobilized Japanese more agitated than the more politically experienced Koreans? Why did professional activists in Japan so effectively use civic groups to integrate into the political mainstream ideas that were once quite marginal, alter the balance of power in political discourse, delegitimize once-robust institutions, and undermine Japanese diplo- 
macy, whereas their counterparts in South Korea failed to generate more than intermittent media attention to their cause? Why, in short, did the same politically motivated abductions by the same enemy actor generate disproportionately powerful effects on the foreign policies of similar states under similar structural circumstances?

\section{The Case of Japan}

Japan's captivity narrative typically begins in November 1977 in Niigata, when a thirteen-year-old middle school student, Yokota Megumi, was heading home from badminton practice. After waving good-bye to her teammates, Megumi was grabbed off the street, trussed, stuffed into a Soviet military cargo bag, shoved into the rusting belly of a fishing trawler by North Korean agents, and deposited in Pyongyang. Her tragedy has had no end: After isolation and reeducation, she taught Japanese at Kim Jong Il Political and Military University, married a South Korean abductee, and was reported to have committed suicide after a nervous breakdown in 1993. Her mother, Sakie, and father, Shigeru, both ordinary parents caught in an extraordinary vise of anxiety, became especially effective advocates for the abductees. Movies, anime, manga all made Megumi a cause célèbre, but her tale and her suffering were not limited to the Yokota household. She was only one of several dozen young people who were either kidnapped by North Korean agents in the late 1970s or who simply disappeared. Some were snatched in Japan, others in Europe. In October 2002, Kim Jong Il famously admitted to Prime Minister Junichiro Koizumi that freelancers within his government had abducted thirteen innocent Japanese youths, but the National Police Agency claims the correct number is forty, and activist groups are championing as many as 500 cases.

Each of these cases connects directly to the core institutions of Japanese politics and diplomacy: civil society, the political class, the media, and the state. They connect to civil society because, after failing to draw public attention to their plight on their own, the families of the abductees attracted support from civic groups dedicated to the overthrow of North Korea. ${ }^{7}$ The two most prominent such groups-the Sukukai (Rescue Association), a combined "support group and political action committee," and the Kazokukai (Family Association) - were set up in March 1997 by professional activists and came to have sizable paid staffs with nearly 100 branches across Japan (see Steinhoff 2008). Leaders of the Rescue Association and related civic groups have used 
the welfare of the abductees and their families to build a national megaphone for their cause. Their success is manifest in many ways, including the role they may have played in authoring legislation to deal with aid to the abductees' families and to stiffen sanctions on North Koreaboth unprecedented for NGOs in Japan, where laws are written almost entirely by bureaucrats.

At first, the families of abductees had trouble gaining public support. On one memorable occasion, the mother of one abductee stood at the Sukiyabashi intersection in Tokyo, possibly the world's busiest crosswalk, for an hour and gathered only one signature for her petition to the government for assistance. Others were criticized for calling attention to themselves. Over time, though, the cause attracted support from civic groups dedicated to the overthrow of the Kim dynasty in North Korea. These groups gained the confidence of grateful abductee families and came to orchestrate their politics by helping them establish their own association, by controlling their access to the media, and by controlling their visits to North Korea. As Megumi's father, Yokota Shigeru, explained about Sato Katsumi, founder of the Rescue Association, "We know Sato is a right-winger, but we need all the help we can get from whomever we can get it from" (McNeill and Hippin 2003).

The Rescue Association gave senior posts to conservative politicians and worked with them to use the abductee issue to derail normalization talks and shift the government's overall approach to North Korea. Within two years, Prime Minister Obuchi declared the abductee issue to be "a matter of personal concern," and Japanese diplomats began meeting North Korean officials wearing the association's blue ribbons as signs of solidarity and protest. On those occasions when the government did not respond as they wished, the Family and Rescue Associations orchestrated sit-ins at the prime minister's office. At the height of their influence, the abductee groups were able to meet with any public official in Japan or in the United States-including the foreign minister, the prime minister, the secretary of state, and the president.

In this way, the Japanese abductions illuminate larger dynamics within Japan's political class. The Japan Communist Party (JCP) has been at odds with North Korea since the 1960s over Kim Il Sung's heterodox Marxism, and it was a JCP staffer who first connected the disappearances to North Korea for the families in January 1988. The Japan Socialist Party (JSP) has had deeper connections to North Korea and to the North Korean-affiliated minority community in Japan. Unfortunately for the families, however, the JSP (today called the Social Democratic Party, or SDP) refused to pursue the allegations, and party lead- 
ers, rather than help secure the release of the abductees, actively covered up North Korean treachery. Members of the now defunct anticommunist Democratic Socialist Party, such as Araki Kazuhiro, became leading advocates of the abductee families. ${ }^{8}$

But it was relations with the ruling Liberal Democratic Party (LDP) that were most valuable for the families and, since the LDP was governing, more consequential for Japanese politics and diplomacy. Pragmatists who sought normalization with North Korea primarily as a way to enrich their own constituents and maintain power had dominated the LDP. But LDP hard-liners rallied to the cause of the abductees, using them to highlight their concerns about national sovereignty, military debility, and regional security. Future prime minister Shinzo Abe, who had never been particularly active on the abductee issue, recognized an opportunity to seize power from the pragmatists. With the support of the parent of Arimoto Keiko, one of the abductees, he and several allies attacked the existing Diet members' League for Early Repatriation of Japanese Citizens Kidnapped by North Korea (rachi giren) as too conciliatory, and formed a more hawkish, suprapartisan group of legislators. This newer association rejected compromise on the abduction issue, called for investigations into the Koreanaffiliated credit unions and an end to all cash transfers to the DPRK, and proposed legislation to prohibit Koreans residing in Japan from visiting North Korea. Abe thereupon also assumed an honorary post in the Rescue Association and stimulated considerable public agitation over the abductee issue in order to engineer an unlikely LDP victory in November 2003 (Abe 2006, 44-46).

As the revisionists consolidated power with the help of the abductee issue, the Japanese right became more prominent. One can see the involvement of the nationalist right in the abductee issue as evidence of the generally rightward drift in Japanese politics. Alternatively, one can see the reverse, a "mainstreaming" of the right, in which once-marginal ideas have been embraced by the center. Those activists and politicians leading the abductee issue have also been active combatants in Japan's culture wars, pressing forward to secure right-wing preferences, such as elevating the emperor, revising the constitution, revising accepted interpretations of the Pacific War, revisiting the conclusions of the Tokyo War Crimes Trial, confronting territorial disputes with Japan's neighbors, and enhancing Japan's national security through the acquisition of more modern weapons.

Public agitation over the abductee issue was abetted, if not created, by a media that awoke late to the issue. For decades, despite a drum- 
beat of reports in the conservative Sankei Shimbun, the mainstream media would not touch the issue, apparently fearing protests by associations of Korean residents and by the left-wing parties. Even after Kajiyama Seiroku, one of the most powerful LDP politicians of the day, testified in the Diet in 1988 that there indeed may have been North Korean kidnappings, no major daily apart from the like-minded Sankei reported his testimony. Indeed, the rest of the (largely center-left) press ignored the issue for sixteen years, until after the institutional suicide of the Socialist Party and the detailed, irrefutable description of the scheme by a North Korean defector.

Then, after Prime Minister Koizumi visited Pyongyang and elicited the formal acknowledgment of the abductions in 2002, the media reversed itself and frothed into high dudgeon. Other issues palled, and substantive policy debate about how to deal with North Korea ceased. It became impossible to question the motives of the families or of their advocates in civil society and the political class. One Diet member said that it would be "political suicide" even to suggest that proliferation of nuclear weapons ought to be of equal or greater concern than the release of the abductees. At that point, the state media stepped in as well. In 2006, the government broadcasting organization NHK was instructed by the Prime Minister's Office to increase radio broadcasting of the issue. According to one senior NHK executive, the mention of any criticism of the way the issue was evolving was "like stepping on a religious icon." An animated film, Megumi, was made with public funds and distributed with a government-produced documentary by consulates around the world. Credible evidence of a cover-up of the results of forensic testing of Megumi's ashes, published in the British journal Nature, was denied vigorously by the government and ignored thoroughly by the Japanese press (Cyranoski 2005).

The relationship of the media to the abductee issue and its contribution to this national convulsion raise important questions about political intimidation in Japan. Both the "nationalist left" and the "nationalist right" seem to have taken turns intimidating the media and politicians. While for decades it had been impossible to criticize North Korea without being attacked by those who viewed Pyongyang as a progressive neighbor, it became open season on those who had been advocating normalization after 2002 . Bullets were mailed to the Tokyo offices of the Korean residents' association (Chosen Soren/Chongryun) by a self-identified "North Korea Suppression Corps," and shots were fired at a Nagoya branch of a Chosen Soren/Chongryun-affiliated bank. A bomb was found at the home of the diplomat who had engi- 
neered the Pyongyang visit for Prime Minister Koizumi, a criminal act condoned publicly by the conservative governor of Tokyo. The home of a leading centrist politician, Nonaka Hiromu, was encircled by sound trucks, forcing him to disband the Japan-North Korea Friendship Association he had championed and convincing him to retire from politics. Meanwhile, abductees and their families were encouraged to draw swords in the culture wars. The mother of a returned abductee spoke at a Diet hearing in favor of constitutional revision. Other Family Association members spoke out in favor of textbook revision and human rights in China-foundational issues on the nationalist right. Some went further and advocated the rounding up and expulsion of all North Korean residents of Japan.

The final domestic institution on which the abductee issue sheds considerable light is the state itself. The aging literature on the "administrative state" had always seemed apt vis-à-vis Japan (Tsuji 1984). Japanese bureaucrats had long been depicted as the best, brightest, most competent, and most incorruptible products of an unassailably meritocratic system. The easy contrast was made to Japan's dim, incompetent, and highly corruptible political class. Politicians, an inordinate number of whom have "inherited" their father's seats, were cast as the "botchan" (princelings) to the bureaucrats' philosopher kings. A succession of deeply troubling scandals and profound bungling-including accidents at unregulated nuclear reactors, corruption of the nation's blood supply while health officials golfed with pharmaceutical executives, and the loss of 50 million pension records-has proved otherwise.

So has the abductee issue. Abductee families complained for years about officials' "unhelpfulness," "arrogance," and "callousness." Hasuike Toru, the elder brother of an abductee, insists that his fight was against both "the rogue nation [North Korea] and the incompetent nation [Japan]" (Hasuike 2006, 138). Fishermen had been reporting strange transmissions and odd vessels to the authorities since the mid-1970s. Nothing was done. Families of those who disappeared from European holidays or study tours were told dismissively by diplomats that "young people often disappear into new lives in Europe." When Terakoshi Tomoe, a charwoman and mother of a suspected abductee, sought help from the Japanese police, they tossed away the letter he had smuggled out to her. The Foreign Ministry kept the issue quiet, it said, so as not to jeopardize the abductees. It is more likely, however, that they were afraid of jeopardizing the delicate process of normalization sought by LDP pragmatists then in power. Once the LDP revisionists consolidated power, the Japanese bureaucrats danced to new music. 
The question, now that the LDP has been crushed, is whether that music finally has stopped - and even if not, whether it is very far past its crescendo. There is a concern among those on the right that the election of the Democratic Party of Japan (DPJ) in August 2009 would lead to a softening in Japan's position on the abductee issue. Although the DPJ was forced by electoral pressures to fall in line with the LDP's tough position on North Korea after 2002, it earlier had favored normalization (Hughes 1999, 171). When they were back benchers in the Sakigake Party, former Prime Minister Hatoyama Yukio and Prime Minister Kan Naoto both went to Pyongyang as part of the Watanabe "rice" mission in 1995. Hatoyama had even signed a petition for the release of a former North Korean spy held in a South Korean jail who reportedly had been involved in Yokota Megumi's abduction (Japan Times, September 17, 2009). Even earlier, DPJ representative Ishii Hajime headed the advance team for the 1990 Kanemaru mission, "unofficial" normalization talks in which former DPJ secretary-general Ozawa Ichiro also played a major role (Ha 2008). The hard-line position indeed had been made precarious by the election: several of the most senior supporters of the abductee families-including the late Nakagawa Shoichi, Sasakawa Takashi, and Nishimura Shingo-lost their seats in the DPJ landslide. ${ }^{10}$ Thus, immediately after the election, the Sukukai organized rallies, and leaders of the Kazokukai visited the prime minister (Yomiuri Shimbun, September 3, 2009; Mainichi Shimbun, September 11, 2009; Kyodo News, September 16, 2009). They may have had reason for concern, but Prime Minister Hatoyama appointed the acting chair of the bipartisan Diet members association on the abductees' issue, Nakai Hiroshi, to the cabinet as chief of the National Public Safety Commission and asked him to look after the abductees. And, in fact, the number of Diet representatives belonging to the Diet members' group on the abductee issue actually increased after the DPJ victory-from 208 to 226, with the additional members overwhelmingly coming from the new ruling party (Yomiuri Shimbun, November 17, 2009).

The Japanese captivity narrative also has international implications, initially and most directly, of course, related to normalization talks with North Korea (Tanaka 2009). If Kim Jong Il thought his 2002 acknowledgment and apology would grease the skids for economic aid and normalization, he seriously misjudged Japan's democratic politics. He got, instead, a "tumult of emotions" (McCormack 2002, 4). Not only was the abductee issue used to consolidate the power of the LDP's revisionist wing, but bilateral relations became much more fraught. The Japanese government revised its Foreign Exchange Control Law, 
banned the entry of the North Korean ferry to Japanese ports, and banned the return to Japan of any resident Koreans who might visit North Korea. Between 1991 and 2003, more than 600 books on North Korea were published in Japan, nearly all "virulently hostile" (McCormack and Wada 2006, 9). No Japanese government was going to proceed on normalization with North Korea while the Japanese public was being lathered into a collective rage by the media, conservative politicians, and groups in civil society with nationalist agendas.

This extended to the multilateral Six-Party Talks on denuclearization of the Korean peninsula. The Japanese government insisted on the return of all abductees during these negotiations, a position that the other participants viewed as a distraction from the more important issue of nuclear proliferation (see International Crisis Group 2005; Kim and Hammersmith 2008). The irony, of course, was that even though the Japanese government had been first to suggest the format, the Six-Party Talks proceeded-under mostly Chinese leadership-without settlement of Japan's primary concern. Getting Japanese negotiators back onto the same page as US, Chinese, South Korean, and Russian negotiators has been declared a central task by DPJ leaders. Hatoyama acknowledged as much by focusing almost entirely on the nuclear issue in his first major speech at the UN General Assembly meeting in New York in September 2009 and by pledging to South Korean president Lee Myung-bak that his government would work on denuclearization of the North (Associated Press, September 24, 2009). However, although Hatoyama signaled to Chinese premier Wen Jiabao and South Korean president Lee Myung-bak that his government would be comfortable with the abductee issue being pursued "in parallel" with the nuclear issue in the Six-Party Talks, he never softened his position on North Korea and there is no indication that Prime Minister Kan, his party colleague and successor, will do so.

Nor have bilateral relations with South Korea been consistently healthy. Japan's position on the abductee issue seems to have reinforced decades of distrust on the peninsula. Not surprisingly, public opinion in the ROK has been sympathetic to North Korean claims of Japanese "plunder" of the peninsula during thirty-five years of colonial rule between 1910 and 1945. The public has been reminded constantly of the abduction of millions of Koreans during the occupation to work as slaves in Japan's mines, factories, and military brothels. Former South Korean president Roh Moo-Hyun linked Japan's colonial atrocities to the current abduction issue and underlined this sense of hypocrisy: "Japan should put itself in Korea's shoes and understand the 
anger of our people who suffered thousands and tens of thousands of times as much pain" (Beal 2005, 343; see also Cumings 2007). This mutual distrust was reflected in a new regional security architecture first proposed by Prime Minister Abe in 2007. His much ballyhooed "arc of freedom and prosperity," promoted to unite the capitalist democracies in the region (presumably to balance a rising China), included Australia, India, and the United States, but pointedly left out South Korea.

For its part, the United States, that never-silent partner in domestic Japanese politics, has been of two minds on the abductee issue. Although President Bush met with Megumi's parents in the White House in April 2006, although US Embassy officials met with the Kazokukai regularly, and although Secretary of State Hillary Clinton met with them during her February 2009 visit to Japan, the US government would not allow domestic Japanese politics to interfere with its larger strategic concern-proliferation of WMD on and from the peninsula. On several occasions, in fact, the abductee issue served to drive a wedge in US-Japan relations. Prime Minister Koizumi visited Pyongyang in 2002, despite White House objections. Tanaka Hitoshi, the chief architect of that visit, writes in his memoirs that the overture had the understanding of Deputy Secretary of State Armitage but was opposed by Defense Secretary Rumsfeld and Vice-President Cheney (Tanaka 2009, chap. 3). He is also reported to have declared, "We don't have to ask the U.S. for approval every time we come up with a foreign policy initiative. We are not a protectorate of the United States" (Funabashi 2007, 88). That may be so, but when the US government removed North Korea from its list of "state sponsors of terrorism" in late 2008, it limited Japan's leverage on North Korea and generated serious and widespread anxiety in Japan about the quality of US commitment to Japanese security and the future of the alliance.

The prominence of the captivity narrative on Japan's official agenda invites questions about the alliance and about the region's security architecture going forward. Capture of the abductee issue by the right in Japan gave reason to expect support for a further strengthening of the Japanese military and a further weakening of Tokyo's diplomacy. For some activists, after all, this was the whole point. Hostility between North Korea and Japan justified the latter's military buildup and the removal of existing constraints on its use of force. The new DPJ government, operating with a more pliant public, claims to have other important priorities. Hence, it is also important to determine if Japan's elevation of the abduction issue and its increasingly muscular rhetoric 
created long-term difficulties with its Chinese and South Korean neighbors, or if the recent shift to a more Asia-oriented diplomacy will open new opportunities for Japanese diplomacy.

\section{The Case of South Korea}

Many of the fundamentals of the South Korean story are remarkably similar to the Japanese one, though they have been painted from a much more chaotic palette. The Red Cross reports that more than 7,000 South Korean citizens were abducted during the Korean War and all but 337 had died by 2002 (Yonhap, September 27, 2002). Abductee family groups claim the number is much higher. One group claims that, according to a 1952 document, 83,000 South Korean citizens, many of them soldiers, found themselves on the wrong side of the demilitarized zone (DMZ) at the end of the war (Yonhap, September 27, 2002). The wartime abductions have been traced to a 1946 memorandum, penned by Kim Il Sung, entitled "On Transporting Intellectuals from South Korea," and to one in 1950 from the Kangwon Province Home Affairs Bureau labeled "On the Cooperative Project Concerning the Transfer of Seoul Citizens." Following the guidelines therein, North Korean soldiers visited private homes seeking specific individuals-primarily intellectuals, journalists, public officials, and students-for forced relocation in the North. While the North's target of 500,000 was beyond ambitious, tens of thousands of southern residents were snatched and transferred to northern mines and farms, particularly in the early months of the war. ${ }^{11}$ In 2009, the government estimated that 560 South Korean POWs were still alive in the North (Jong Ang Daily, September 29, 2009).

The numbers of abductions subsided after the war but were never eliminated. A steady stream of abductions is recorded from 1953 to the present. The Korean Institute for National Unification reports that nearly 4,000 ROK citizens-including five high school students and a schoolteacher visiting Norway-have been abducted to North Korea since the armistice in 1953 "partly because North Korea may have found their knowledge and manpower useful" (Korea Institute for National Unification 2005, 313-315, Appendix1). ${ }^{12}$ Most of the postwar abductees were fishermen, but sailors, students, and passengers aboard a hijacked KAL flight were also kidnapped. Like their Japanese counterparts, South Korean high school students were swept off beaches by North Korean agents in the late 1970s. Some 500 of the postarmistice 
abductees are believed to remain alive and in detention across the thirty-eighth parallel today. ${ }^{13}$ Some of these abductees have been used to train North Korean agents at the Center for Revolutionizing South Korea, a Potemkin village-like replica of the ROK for graduates of the Kim Il Sung Political Military College. According to government officials, others were themselves trained as spies, and some broadcast propaganda to the South. ${ }^{14}$ For this reason, all returned abductees were suspected North Korean agents and all were subjected to intensive interrogation, sometimes including torture. ${ }^{15}$ Complicating this were the abductions of some 100 ethnic Koreans with Chinese citizenship, most of whom had been involved in efforts to help North Korean refugees escape across the northern frontier. ${ }^{16}$ Pyongyang, for its part, has always denied holding any South Korean nationals or ethnic Koreans from China against their will, though it has from time to time responded positively to calls for resolution of the status of missing persons (Korea Institute for National Unification 2009, 384). ${ }^{17}$

As in Japan, the abductee issue connects to-and illuminates-the core institutions of South Korean national politics: civil society, the media, the political class, and the state itself. The first stirrings of Korean civil society on the abduction issue came during the Korean War, when the Korean War Abductees Family Association (KWAFA) was established in September 1951 in anticipation of an agreement for family exchanges after the armistice. Although KWAFA helped the government and the Red Cross compile five official lists of tens of thousands of abductees, none were ever acknowledged or returned by the DPRK. ${ }^{18}$ Failing to achieve its goals—in part because some "escaped" abductees returned to the South as North Korean spies-KWAFA was disbanded in June $1960 .{ }^{19}$

After a period of general quiescence on the abductee issue, several new groups appeared after the June 2000 Kim Dae-jung/Kim Jong Il "Sunshine summit." The Families of Abducted and Detained in North Korea (FADN) was formed by seven abductee families in February 2000 , but a group preferring a more aggressive political agenda, the Abductees Family Union (AFU), split away soon thereafter. In November 2000, members of the wartime KWAFA - and their childrencreated the Family Group for the Korean War Abducted Persons. It again changed its name to the Korean War Abductees Family Union (KWAFU), in September 2001, and compiled a list of nearly 95,000 abductees for whom it demanded a full accounting (Korea Institute for National Unification 2009, 383). The Citizen's Coalition for Human Rights of Abductees and North Korean Refugees (CHNK) was organized in March 2001 by Do Hee-yoon, a former student activist and 
graduate of the patriotic Young Korean Academy (Heung Sadan), to coordinate the activities and demands of some twenty-five different NGOs. ${ }^{20}$ In July 2009, seven South Koreans who had been kidnapped and held for decades by North Korea formed the Returned Abductees' Committee to raise awareness of the issue. One leader, Go Myungseob, spent twenty-nine years in North Korea after being kidnapped from a fishing boat in 1975 along with thirty-two other men. Other leaders include Lee Jae-geun, the first abductee to escape and return to the South, as well as three North Korean defectors who refused to be identified (Radio Free Asia, July 22, 2009).

Activists and officials suggest several ways to categorize the South Korean abductee associations. The range of NGO demands is, indeed, quite wide-and has changed over time. According to Lee Keum-soon at the Institute for National Unification, "Before the 2000 [Sunshine] summit, even the families paid little attention [to the abduction issue]. They did not know if their relatives were abducted or simply missing."21 According to Koo Byoung-sam, the official at the Ministry of Unification responsible for liaison with these groups, they can be distinguished by their tactical preferences. The more assertive groups, like AFU, he suggests, are "issue makers." 22 Indeed, AFU's president, Choi Sungyong, claims to have "agents" in North Korea. Choi was responsible for confirming the identity of Kim Young-nam, the teenage abductee who became Yokota Megumi's husband. Choi claims that he has been so vocal that the South Korean government provided him office space in a commercial building in downtown Seoul. He attributes the unusually heavy security of this building to "death threats from North Korea." 23

Koo labels KWAFU and other, more passive, groups "information gatherers" who seek to establish facts that would justify their claims. Lee Mi-li, president of KWAFU and daughter of an abductee, describes her group's activities in just this way, specifying that its primary goal is to get information on wartime abductees from North Korea and believing that the Sunshine Policy would purchase this information. But she insists that the important difference is between the wartime groups and the postwar ones, noting that the former receive no compensation under the law, and suggesting that the latter do not fully respect their claims and rights. ${ }^{24}$ Other observers note that some groups are more interested in maximizing the compensatory stipends due them under the 2007 legislation than in pursuing a larger political agenda, but most acknowledge that for many, the "recovery of honor" is of paramount importance. ${ }^{25}$

As in the Japanese case, some South Korean abductee groups sought and found common cause with more broadly based conservative 
and anticommunist groups in civil society. While FADN and KWAFU have been generally apolitical, AFU has been highly mobilized, engaging in both legal and illegal activities, including protesting in front of the Ministry of Unification (MOU) minister's home, harassing members of the victim recognition deliberation committee, and reportedly hiring agents to infiltrate North Korea (Arrington 2007, 14). ${ }^{26}$ AFU claims to have helped all eight of the escaped abductees reach South Korea. After sending balloons across the DMZ with the names of abductees and drawing strong protest from the DPRK in 2008, anticommunist NGOs, including AFU, sent North Korean banknotes and propaganda fliers aloft across the border in 2009. The South Korean government considered legal measures to block these acts but reportedly was intimidated by the ability of such anticommunist NGOs as Fighters for a Free North Korea, in alliance with the AFU, to mobilize conservative opinion (Korea Institute for National Unification 2009, 21; Korea Times, February 16, 2009). Unlike in Japan, however, where the alliance of conservative culture warriors and abductee family groups enjoyed broad support that led to significant policy changes, these actions were met with disinterest and even opprobrium from the general public, the government, and other abductee/refugee organizations in South Korea. As noted earlier, even the eight abductees whom the AFU claims to have rescued formed their own civic group out of a concern that the AFU activism was counterproductive.

For most of the past fifty years these groups have achieved very little. Activists attribute their inability to affect South Korean policy to inattention by the media, and government officials agree, suggesting that the abductee issue in South Korea "is difficult to publicize" (Korea Institute for National Unification 2009, 384). ${ }^{27}$ Although the return home of an abductee-the aforementioned Lee Jae-geun escaped from North Korea that same month-attracted considerable media attention, the press was otherwise largely uninterested in the abduction problem. As in Japan, conservative newspapers, like Chosun Ilbo, have paid closer attention to the abductee issue than have progressive ones. But overall, there has been little sustained coverage in the Korean media. The MOU official responsible for the issue reports that media attention has been "sporadic" and that since 2007 he has been contacted more often by the Japanese than by the Korean press. ${ }^{28}$

This is not to suggest that the South Korean media was uniformly uninterested or that, as in the Japanese case, their lack of attention was the product of political intimidation. Indeed, there have been moments when the abductee issue flared into fuller view—often fueled by nega- 
tive comparisons of ROK efforts with what are perceived as Japanese (and later, US) "successes." The admission of the abductions and the apology by Kim Jong Il to Prime Minister Koizumi in October 2002 reopened the issue of North Korean kidnappings of South Korean citizens "in a more explosive political and social form" (Yonhap, September 27, 2009). Two days after the October 2002 Pyongyang Declaration, FADN and KWAFU petitioned the South Korean government to put the abductee issue on the agenda for any future unification talks (Yonhap, September 19, 2002) ${ }^{29}$ ROK citizens resented that the Japanese received an apology and acknowledgment while they were stonewalled. According to Yonhap, "the issue became fodder for opposition parties and civic groups to pressure the government" (Yonhap, September 19, 2002). Mirroring the demands of Japanese groups, some South Korean NGOs demanded that Seoul withhold all aid to Pyongyang until the abductee issue could be similarly rectified. Opposition presidential candidate Lee Hoi-chang "bashed the government," promising to do more to get Pyongyang to answer for the kidnappings (Yonhap, September 19, 2002). One conservative editorial, reacting to the situation of an abducted fisherman, Im Guk-jae, fairly shouts at the ROK government:

When he was abducted, Im believed that his country would rescue him soon. He waited and waited, and for fifteen long years his country did nothing. . . . Im is now presumed to be in a concentration camp. Cold political logic aside, has the government of the Republic of Korea ever had a shred of feeling for the man? (Chosun Ilbo, February 23,2005 )

Resentment of the ability of the Japanese and US governments to succeed with Pyongyang continued to run high in South Korea-this, despite the fact that Choi Woo-young, a founder of the FADN, explicitly acknowledges the Japanese Kazokukai as a model in the formation of his group in February 2000. ${ }^{30}$ In April 2006, a newspaper editorialized that Seoul "should be ashamed" that Tokyo was doing its job for it on the abduction front (cited in Arrington 2007, 17). In August 2009, former US president Bill Clinton traveled to Pyongyang to secure the release of two US reporters who had been captured by North Korean soldiers after they entered DPRK territory. Abductee NGOs in the Republic of Korea had the same reaction to their release that counterpart groups in Japan had-exasperation that American pressure worked and frustration with their own governments for their inability to secure the release of their own, longer-suffering (and more innocent) brethren 
(Korea Times, August 7, 2009). The Chosun Ilbo frames the criticism of Seoul against the successes of Washington and Tokyo:

The United States and Japan, quite unlike South Korea, never slacken the reins in demanding due protection of their own nationals from the North while squarely facing Pyongyang on its nuclear program. ... The $[R O K]$ government cannot even find the right words to bring its own citizens home when the North abducts them, yet it continues to give Pyongyang billions of dollars in food and fertilizer aid every year. That is what it calls dialogue. (Chosun Ilbo, February 23, 2005)

More recently, it editorialized:

Officials from the previous two administrations sat down in hundreds of meetings with North Koreans but did not dare even to mention the issue.... If Seoul were to show the same resolve as the Japanese government, with the president or prime minister personally leading a committee focusing on the issue, the family members of POWs, abduction victims and other members of separated families could at least have some hope. (Chosun Ilbo, October 16, 2009)

But support for Japanese efforts has been mixed in South Korea. In August 2007, the Investigation Commission on Missing Japanese Probably Connected to North Korea (Tokutei Shissosha Mondai Chosakai), a particularly insistent Japanese abductee group led by Kazuhiro Araki that had split from the Rescue Committee, attempted to release several balloons from South to North Korea with information about missing Japanese suspected of being in the DPRK. The effort was opposed by FADN, which claimed that such an attempt would adversely affect scheduled meetings of the Red Cross on the abductee and POW issues. Some suggest that the sympathy of Koreans for the Japanese abductees is limited by a well-documented history of Japanese abductions of Korean women and sex slaves. As one government official explains, "Because of Japanese colonialism, Koreans in the north and south have a deep sense of distrust [of Japan]." ${ }^{31}$ AFU's Choi, a former civil servant who once had collaborated with Araki's Investigation Commission's balloon projects, has testified in the Japanese Diet but now insists he "would not return to Japan even if invited." ${ }^{32}$ Choi suggests that "our characteristics conflict. Japan's approach is too political. [The abductee issue in Japan] is part of a bigger agenda. Abduction is a crime and should not have been negotiated. You do not negotiate with criminals." 33 
Many other aspects of the Japanese approach are problematic for Choi, including how the Japanese government and civic groups forced the returned abductees to remain in Japan, abandoning their children in North Korea. Choi is also put off by the behavior of the Japanese media. When he returned from North Korea with seven abductees, he says the news barely was reported in Japan, even though unconfirmed rumors about Japanese abductees are heavily covered. He concludes sardonically that "Japan only talks about itself." But his larger complaint is with Kim Jong Il, who apologized to the Japanese while denying any abductions of South Koreans. ${ }^{34}$

Still, there has been useful collaboration between South Korean and Japanese abductee activists-particularly among those whose larger goal is the "punishment" of the North Korean regime. ${ }^{35}$ Mr. Do reports regular ties and meetings with Mr. Araki and says that his Citizens' Commission and Araki's Investigation Commission plan jointly to appeal their respective cases to the International Criminal Court. ${ }^{36}$ Nor are these ties limited to the more ideologically oriented groups. President Lee of KWAFU reports having been invited to meetings by leaders of both the Japanese rescue and the family associations. She has met with Yokota Megumi's father, Shigeru, as well as with activists such as Sato Katsumi and Araki Kazuhiro. Abductee groups in both countries, moreover, have found common cause in a multinational coalition of abductee groups that include NGOs from Romania, Thailand, Vietnam, and the United States. ${ }^{37}$

Several reasons have been advanced to explain the South Korean media's treatment of the abductee issue, some of which highlight the complicity of the South Korean government itself. Unlike Japan, where the abductees were so clearly innocent youths, many of the Korean abductees could not be distinguished easily from defectors. As a result, the return of those who were away less than two years was met with considerable suspicion by the government officials with responsibility for state security. Rather than welcome them home, South Korean intelligence officials considered the returnees security risks and aggressively interrogated them, never quite absolving them of suspicion. Their families were likewise closely monitored and subjected to various forms of discrimination in the workplace and in education. Until 1989 , they were barred from government jobs-most notably from entrance to the military academy - and were subject to government surveillance. ${ }^{38}$ Not only had they suffered with the rest of the nation through a devastating war, and not only had they lost loved ones about whom there was no information, but now they were treated as likely 
spies for the North and sanctioned officially (Arrington 2007, 10). At the same time, according to one analyst, many families of missing persons avoided making public demands both because they understood this would attract state sanctions and, in some cases, out of a concern that investigations might reveal more than they wished known about their relatives. ${ }^{39}$

There is also the issue of official recognition. KWAFU has argued that by acknowledging fewer than 500 abductees, the Seoul government has denied the existence of Korean War abductions. Angry at the government's use of terms such as missing persons or separated family members rather than abductees, the KWAFU filed suit against the government in 2006 (Yonhap Weekly North Korean Review, January 19, 2006). Lee Mi-li, the KWAFU leader, insisted that these people be called "what they are-kidnapping victims" (Yonhap, September 27, 2002).$^{40}$ The FADN lost a similar suit in 2002 both in the lower court and on appeal (Arrington 2007, 15-16).

These separate suits belie a more significant problem - the wartime abductees' organizations and the postwar ones never united under a single banner. The latter have been focused exclusively on compensation and the immediate return of their loved ones, whereas the former focus on confirmation of their relatives' whereabouts and on family reunions (Jong Ang Daily, September 29, 2009). ${ }^{41}$ Some 127,000 South Koreans have applied for cross-border family reunions, but fewer than 500 a year have participated in the limited number of meetings arranged to date (Chosun Ilbo, October 16, 2009). Moreover, as noted earlier, ideological splits in the postwar groups and the inability of the right to monopolize the human rights agenda in South Korea have rendered the abductee issue a less powerful political tool in South Korea than it has been in Japan.

The South Korean government raised the issue of the missing only intermittently with the North and never used it as the sine qua non for normalization as did the government of Japan. To the contrary, with the DPRK refusing to acknowledge holding POWs or abductees, the South Korean government turned to what it considered a "more realistic" term: "separated" families (Ministry of Unification 2005, 101). But even then, progress and media attention were limited. Although there have been dozens of escapes and defections, by 2004 only nineteen families had been temporarily reunited, and as late as 2009 , the DPRK continued to refuse to discuss the abduction issue. Whether defectors or not, the fact is that the abduction issue is only part of the larger problems of displacement and family division that affect a much larger 
number of South Koreans. Thus, abduction is subsumed under-and is clouded by-some of the most vexing issues in Korean social and political life.

This is reflected in the way the Korean state is organized to deal with the abduction issue, an issue that has never been high on the government's list of priorities. For years, according to one official, "we worried more about spies than about abductees." 42 Responsibility for the abductees - their identification, their return, and compensation to them and to their families-resides in the Ministry of Unification, where precious few resources are dedicated to the problem. The abductee office was created only in 2000 and is occupied by just a single official who describes his work as "frustrating." 43 The official spends time meeting with or talking by telephone to abductee group leadersparticularly AFU's Choi, with whom he reports "two or three contacts each week," and with KWAFU's Lee, with whom he reports weekly contact. $^{44}$ Other agencies-the National Police Agency, the Coast Guard, the National Intelligence Service, the Ministry of Food, Agriculture, Forestry, and Fisheries, and the Ministry of Foreign Affairs and Trade-are each involved with the abduction issue. But abduction is routinely subsumed under their larger, even more difficult responsibilities. In the case of the National Police Agency, for example, abductee issues are handled by the office on defectors. A special Bureau for Compensation is staffed by secondees from several of these other units.

The 2007 legislation provides compensation for three categories of victims. If they were abducted for more than three years, the abductees themselves receive up to 200 times the minimum monthly wage, in addition to housing and medical support. As of 2009, eighteen individuals qualified for this compensation. The families of the abductees receive up to thirty-six times the minimum monthly wage as compensation for their loss of jobs and other state-mandated discrimination. As of 2009, more than 500 families received these allowances. The final category for compensation is "disabled persons." This is a euphemism for those abductees who were tortured and physically maimed by the South Korean state. As of 2009 , only one individual received benefits under this category, but seven more cases are under consideration. Complicating this investigation is the fact that many of the torturers remain in government and are fearful they will be identified..$^{45}$ The irony of all this, according to one activist, is that there has not been a single confirmed case of a returned abductee confirmed to be a spy. To the contrary, he suggests, there were many cases in which the South Korean government falsely accused individuals of spying for political reasons. As he put it directly, 
"To explain the government's position, one must consider the unification issue in general. South Korea could not be too tough because it, too, was an offender." 46

This is clearly linked to the authoritarian nature of Korean politics before 1987 and to divisions within the political class since then. State vigilance vis-à-vis defectors and returned abductees did not end after the transition to democracy in South Korea. By most accounts-as in Japan prior to 1998-the prospect of normalization and reconciliation prevented South Korean leaders from pressing the North for change in the abductee status quo even after the democratic transformation. Whereas the predemocratic ROK faced little pressure from public opinion, progressive forces in democratic Korea were reportedly so keen on reconciliation and its Sunshine Policy that it soft-pedaled the abductee issue for fear of running the talks off the rails. Celeste Arrington suggests that the families' demands were "sidelined" because "the government was loath to risk "big losses [by upsetting the talks] for small gain [for the families of the abductees]"' (Arrington 2007, 2).$^{47}$ One activist insists that abductee groups were ignored by progressive governments because "they did not want problems surfacing during their negotiations with the North," adding accusingly that "Kim Dae-jung promoted democracy for his own political gain." 48

The cynical view of the Kim policies is often extended to the Uri Party and Roh Moo-hyun's regime as well. Human rights and abductee activists express more optimism about the conservative Grand National Party, which took power in 2007 under Lee Myung-bak. This larger political division between "progressive" and "conservative" forces may be reflected within the Korean state structure, as there are reportedly still some within the bureaucracy who remain loyal to Kim Dae-jung and to Roh Moo-hyun's policies. ${ }^{49}$ For these various reasons, then, the demands of the abductee activists have often been suppressed-even after the shift to democracy in 1987. According to one official, the very idea of identifying and retrieving the abductees has long been viewed as "mission impossible." 50

As we have seen, while fundamental elements of the abduction story are the same as in Japan, the South Korean policy outcomes have, on balance, been quite different. We note, with Arrington, that South Korean and Japanese groups became particularly active at the time of a potentially historic change in international affairs (Arrington 2007, 2). In both countries, moreover, families organized NGOs to press their case to the government and became more assertive after forming working alliances with broader, more ideological and nationalist groups- 
human rights advocates in South Korea and revisionists in Japan. Despite efforts to coordinate their demand making, however, South Korea's multiple civic associations have been far more fractured than Japan's and have had far less political impact. ${ }^{51}$ As in Japan, the Korean media have been inconsistently attentive to the issue but have neither suffered the intimidation nor exhibited the sharp swings that characterized Japanese coverage of the abductee issue. Finally, we observe much thinner connections in Korea between the NGOs and both the political class and the state. ROK leaders were able to ignore the media and interest groups with an insouciance that their Japanese counterparts could not sustain. What explains this?

\section{Conclusion}

We can begin with the difference between Japanese and South Korean international relations. Notwithstanding the many parallels noted in the previous discussion-particularly the fact that both countries face the same principal enemy with the support of the same powerful ally-Japanese politicians may have been freer to focus on the abduction issue and use it for domestic political gain. This is plausible to the extent that Japanese leaders feel more secure from DPRK attack than their ROK counterparts, despite recent nuclear and missile threats. Indeed, we note that Japan experienced a spasm of national indignation on the abductee issue and hardened its diplomacy toward the DPRK only after reaffirming with unprecedented vigor its allegiance to the United States after September 11, 2001. South Korea, by contrast, may have been more reluctant to push the abductions issue because of the impact on national security interests and greater concerns over aggravating North Korea. In short, the security context seems to provide room that political actors can then exploit to their domestic political advantage. Still, as we have seen, there has been little Japanese softening toward the DPRK in recent years, even though the US security commitment has come into question (Finnegan 2009; Madsen and Samuels 2010). Absent further evidence, therefore, this intuition falls well short of providing a comprehensive explanation for policy differences in these cases.

We are obliged, therefore, to look more closely at domestic factors to make sense of the divergence in South Korean and Japanese abductee politics-ideology, partisanship, and institutions in particular. Jack Snyder's model, as reviewed earlier, is most helpful with the latter-particularly with reference to the Japanese case. As he anticipates, the ab- 
ductee groups in civil society (allied with, and organized in part by, nationalist activists) won national attention at about the same time that LDP revisionists consolidated power from LDP pragmatists (Samuels 2007). Power was newly "cartelized," making it possible for groups favoring an aggressive posture on the abductions to combine effectively with those favoring a more muscular security posture and together effectively shift-Snyder would say hijack—national policy. The media (and with it public opinion) flipped, ensuring that a hard-line view would be the default position of Japan's national leaders. Logrolls, misperceptions, and miscalculations ought to have been easier than ever, and that too is what we observe: Japanese foreign policy became so entangled in the abductee issue that Japanese diplomats ceded their standing in the Six-Party Talks to the Chinese and accomplished few of their larger security aims.

Arrington, in her analysis of these two cases, takes a slightly different, but not unrelated, institutional tack. Attributing policy differences to changes in "the relative power of the executive" in each country, she suggests that by 2000 , the political class in both South Korea and Japan had come to dominate the career bureaucracy in matters of public policy (Arrington 2007, 17, 21-22). She argues that the shift in "the relative power of the executive" enabled Japanese and South Korean politicians to pursue their preferred paths vis-à-vis the abductees and North Korea. In Japan this meant a more hard-line course than in the past - that is, a sharp veering away from normalization in favor of sanctions and a military buildup. In South Korea, this meant the continued ability of presidents to ignore activists with impunity. This is plausible, especially when combined with Snyder's suggestion that the key to the hijacking of national policy rests in the extent to which foreign policy decisionmaking can be cartelized by powerful interests.

But there are several reason why these institutional explanations fall short as well. First, we cannot know that ROK leaders insulated themselves from public demands by nature of their presidency, because the public largely shrugged off the issue in South Korea where abduction is deeply embedded in much larger and more complex security concerns. Moreover, the ROK government's complicity in the denial of civil rights to abductees suspected of spying and defection provides further incentive for the government to ignore demands from abductee groups. Likewise, in Japan until the 2000s, the preferences of the pragmatic wing of the LDP were consistent with those of the professional bureaucrats. Both wanted to explore normalization with Pyongyang and both therefore preferred to ignore the abductee issue. It was not 
until hard-line LDP leaders with a demonstrated antipathy for North Korea consolidated power that the abductee issue was elevated in the national discourse. These leaders did not depend on administrative reform for their empowerment as much as they depended on their own electoral success.

If either the cartelization of interests or the centralization of executive authority is to explain South Korean and Japanese responses to the abductee issue, we should also observe change over time in each case. But there is little change in the South Korean case, despite the extraordinary shift from authoritarianism to democracy in 1987. Political preferences and the abductee issues have been aligned across that great structural divide. Before 1987, South Korean civil society was underdeveloped, and without elections organized interests could be ignored by the state with impunity. But how can we explain this same outcome after competitive electoral institutions were established? That we observe marginal change in government policy on the abductee issue and only limited vulnerability to pressure from the abductee groups suggests the weakness of the groups at least as much as the structural insularity of the politicians. It is not reasonable to assume that the centralization of executive power-or the cartelization of interests-was the same after 1987 as it was before democratization. If structural change were a plausible explanation, we should be observing changeand far more pressure on the executive.

There clearly was more change in the Japanese case. As Snyder would expect, we did observe a "mainstreaming" of the right and a closing of ranks around nationalist, if not expansionist, goals for a time. We also observed the cloaking of these ideas in the mantle of national interest. But now that the LDP has been routed and the "cartel" of revisionists and nationalist interest groups has been displaced, we should expect less hawkish policy toward the DPRK and a return to the "normalization" path-what Snyder refers to as a correction for excesses. At a minimum, we should expect the abductee issue to become less determinative of Japanese foreign policy. Indeed, the DPJ promised to wrest control of public policy from the hands of the bureaucrats, and thus has been busy attacking Snyder's "cartel." In the event, however, Prime Minister Hatoyama shifted Japanese policy on the abductees and the DPRK very little. He met repeatedly with Kazokukai leaders and appointed a DPRK hard-liner, Nakai Hiroshi, to the cabinet to serve as both national public safety commissioner and "abductee issue czar." Nakai added Investigative Commission activists to the Abduction Policy Headquarters and, in February 2010, announced that the Japanese government would exclude 
Pyongyang-affiliated schools from the new government's policy of waiving tuition fees for high school students. ${ }^{52}$ The prime minister meekly followed suit in what was widely reported as a new effort to ratchet up pressure on North Korea (Mainichi Shimbun, March 14, 2010). Nakai was reappointed to the same posts by Prime Minister Kan.

We turn, then, to ideological explanations. Brad Williams and Erik Mobrand (2010) make a compelling case for the relevance of ideology. They contrast Japan's "restorationist nationalism" with South Korea's "ethnic nationalism" and conclude that these fundamentally different ideas explain why calls for the return of abductees were smothered in South Korea, while they fueled enthusiasm for muscularity in Japan. Arrington $(2007,21-22)$ notes that engagement with North Korea became a near-hegemonic policy idea in South Korea under "pro-engagement progressives" such as Kim Dae-jung and his successors. Indeed, it has been widely reported that Kim (himself kidnapped and nearly assassinated by the predemocratic ROK intelligence services in 1973) did not encourage or empower the abductee groups. But as we have seen, even the conservative Lee government seems quite clear that efforts by NGOs to undermine DPRK authority are unwelcome. We have documented continuity in Japanese policy as well-at least after the revisionists of the LDP gave way to the progressives of the DPJ. Hence, we cannot fully credit ideology as a consistent predictor of the differences we observe.

This suggests that partisanship also fails to do sufficient heavy lifting. One explanation of the failure of the ROK government to act is that both the Kim Dae-jung and Roh Tae-woo governments did not have to contend with (or mollify) conservative factions, allowing them space to focus on engagement with Pyongyang and weakening the political access of forces opposed to it. But with the onset of the Lee Myung-bak government, South Korean policy persists. Nor, as previously reported, was the transition from sixty years of LDP governance to DPJ rule accompanied by a softening in diplomacy toward Pyongyang or a turn away from the Japanese family associations and their right-wing allies.

Thus, we have here more than a story of successful and unsuccessful "mobilization" of (and "capture" by) interest groups in Japan and Korea. Policies often changed-or failed to change-without regard to shifts between "cartelized" and competitive structures or structural stasis. Nor has there been sufficient structural change in the regional security system to credit international factors with causal power. Finally, as we have seen, neither ideology nor partisanship can carry the full interpretive load. We have here parallel stories of opportunistic political 
leaders who have been able to operate effectively to their own political advantage within a wide range of domestic and international constraints. The ROK political class that focused on improving relations with the DPRK was determined to prevent human rights issues (including abductions) from interfering with their larger political agenda. In Japan, too, an entire regime was replaced, but its priorities have remained politically viable.

In short, then, the policy differences we have identified defy systematic structural or ideological explanation in either the international or domestic arenas. They remind us that political agency operates within the constraints of domestic and international politics but that these constraints-including institutions, ideology, and partisanshipcan be stretched and exploited by skilled political actors. This is, of course, an old lesson, but it is one of which we frequently need reminding: neither the structure of international power nor the institutions and animating ideas of domestic politics individually determine policy choice.

Richard J. Samuels is Ford International Professor of Political Science and director of the Center for International Studies at the Massachusetts Institute of Technology. He is founding director of the MIT Japan Program and was elected a member of the American Academy of Arts and Sciences in 2005. Samuels's most recent books are Securing Japan: Tokyo's Grand Strategy and the Future of East Asia (2008) and Machiavelli's Children: Leaders and Their Legacies in Italy and Japan (2003).

\section{Notes}

I would like to thank the EAI Fellows Program on Peace, Governance, and Development in East Asia, supported by the Henry Luce Foundation of New York and the Chiang Ching-kuo Foundation for International Scholarly Exchange of Taipei, for their generous support in providing resources for travel and research. Thanks to David Weinberg and Jonghyuk Chung for their research assistance and to Celeste Arrington, David Leheny, and T. J. Pempel for comments on an earlier draft. Comments from Lee Sook-jong, Kim Sang-joon, Nam Chang-hee, Lee Myon-woo, and Koo Min-kyo at a seminar in Seoul were especially productive. So were suggestions made by two anonymous referees. This is the first paper in a larger project on political captivity in the United States and five of its allies: South Korea, Japan, Colombia, Israel, and Italy. Comments are welcome: samuels@mit.edu. 
1. A history of the politicization of captivity would include narratives from antiquity, such as in the Book of Judges, Helen of Troy, and the Rape of the Sabine Women. It would also document how kidnappings by Barbary corsairs were used by civic groups and politicians in Britain and North America to build militaries and compensate victims in the seventeenth and eighteenth centuries. A generation later, in Russia, kidnapped soldiers were immortalized by Alexander Pushkin and credited with bringing civilization to the Caucasus. Tales of the capture of settlers by Native Americans were used by preachers and novelists to forge an "American identity" and Teddy Roosevelt secured the GOP nomination for president in 1904 by promising to mobilize the fleet to free a US citizen held captive in North Africa. More recently, the POW/MIA issue of the 1970s, the Teheran hostage crisis of the 1980s, and the fabricated "rape and capture" of Private Jessica Lynch in Iraq in 2003 are all examples of efforts to stir emotions in order to shape US national policy. For excellent accounts of these and other cases, see Slotkin (1973), Miller (1997), Colley (2002), Faludi (2007), and Grant (2009).

2. Arrington (2007) uses these same cases as example of "victims' organizations"-advocacy groups comprising individuals who blame the state for the physical harm they or their family members suffered. Hasuike Toru, the brother of one of the Japanese abductees, briefly but incisively compares the two cases. See Hasuike $(2009,52)$.

3. Arrington (2007) reviews the domestic policy capture literature using the same cases as cited in this article. Also see Williams and Mobrand (2010) for this paired comparison.

4. Today more Japanese regard their bureaucrats as more untrustworthy than their politicians-but each group is distrusted by over three-quarters of the population (Tokyo Shimbun, June 14, 2009).

5. See http://panel.gallup.co.kr/svcdb/condition_content.asp?objSN= 19940701007 (accessed September 11, 2009).

6 . Until 2001, the dispersed family issue was considered the top priority. It is possible that the abductees issue was perceived as part of the dispersed family issue, but it seems that the South Korean public paid little attention to the issue of abduction until after the revelation of Japanese abductees. It is of some interest that, as in Japan, those who oppose the South-North dialogue show more interest in the abductee issue.

7. The best work to date on this issue has been in English by Johnston (2004); McCormack and Wada (2006); Morris-Suzuki (2009); and Arrington (2007). For the families' own stories, see Kitachosen ni Ratchi Sareta Kazoku ni yoru Renrakukai (2003); Hasuike (2009); and Yokota (2009). Sato (2004) is an account for schoolchildren written by the leading Sukukai activist.

8. Araki, who had worked with the Rescue Association, split off to establish his own Investigative Commission on Missing Japanese Probably Related to North Korea.

9. Author interview, Tokyo, January 2009.

10. Former prime minister Shinzo Abe was the only LDP Diet member to attend the first major rally organized by the Sukukai after the election (Yomiuri Shimbun, September 8, 2009). 
11. Center for North Korean Human Rights Studies, Korea Institute for National Unification, ed., (2009, 19, 380-381). Author interview with Koo Byoung-sam, Ministry of Unification, Seoul, December 16, 2009.

12. The report (p. 317) presumes that abductees who were not deemed useful as teachers or guides for North Korean agents were sent to the North Korean gulag. The estimate of wartime abductees by Kim (2006) is slightly lower and finds that only a small minority were soldiers. See also Shun (2002).

13. Ministry of Unification $(2005,100)$, and Center for North Korean Human Rights Studies (2009, 20, 384-385).

14. Center for North Korean Human Rights Studies (2009, 391-395). Author interview with Bae Youn-soo, Ministry of Unification, Seoul, December $18,2009$.

15. Author interviews with Bae Youn-soo, Ministry of Unification, Seoul, December 18, 2009, and with Lee Mi-li, KWAFU president, Seoul, December 17, 2009. See also Williams and Mobrand (2010).

16. Author interview with Choe Chang-woo, Anti-Corruption and Civil Rights Commission, Seoul, December 18, 2009.

17. In what was called an "exchange of dispersed persons" (emphasis added), the DPRK also released nineteen foreign nationals after the armistice, but no South Koreans (Korea Institute for National Unification 2009, 382). When the North Korean Red Cross finally responded to South Korean calls for the return of abductees in 1957, it included a request for information on the status of more than 14,000 North Koreans it claimed were missing and held in the South (Korea Institute for National Unification 2009, 382).

18. Pyongyang released only the fifty-five non-Korean civilians (mostly European clergy, diplomats, and reporters) it claimed were being "protected" during the conflict. Author interview with Lee Mi-li, president of KWAFU, Seoul, December 17, 2009.

19. Author interview with Lee Mi-li, president of KWAFU, Seoul, December 17, 2009. Williams and Mobrand (2010, 526).

20. The Young Korean Academy was founded, shortly after the Japanese occupation began, to promote nationalism and independence. See http://www .dosan.org/hungsadan.html. Arrington $(2007,5)$ reports that the FADN, which she describes as "docile, invisible, and less nationally unified," is the Korean group that is most similar to the Japanese Kazokukai. See http://www.rehome .or.kr (FADN); http://625.in/en/index.php (KWAFU); http://www.chnk21 .org/kimsboard7/inc.php?inc=intro2\#03 (CHNK); http://comebackhome.co.kr/ home/home/best (Association of Abductee Families).

21. Author interview with Lee Keum-soon, Korea Institute for National Unification, Seoul, December 16, 2009.

22. Author interview with Koo Byoung-sam, Ministry of Unification, Seoul, December 16, 2009.

23. Author interview with Choi Sung-yong, Abductees' Family Union, Seoul, December 21, 2009.

24. Author interview with Lee Mi-li, president of KWAFU, Seoul, December $17,2009$. 
25. This term refers to the humiliation family members suffered from the official description of their relatives as "defectors from South Korea." There is an effort under way to extend the "recovery of honor" to the Korean War-era family members as well. Author interview with Bae Youn-soo, Ministry of Unification, Seoul, December 18, 2009.

26. According to Arrington (personal communication), AFU and FADN rarely cooperate. In July 2007, their animosity became national news when the AFU disrupted a public hearing and assaulted the leader of FADN.

27. Author interviews with Do Hee-yoon, Citizens' Commission for Human Rights and North Korean Abductees, Seoul, December 15, 2009; Koo Byoungsam, Ministry of Unification, Seoul, December 16, 2009; Lee Mi-li, president of KWAFU, Seoul, December 17, 2009; Lee Keum-soon, Korea Institute for National Unification, Seoul, December 16, 2009; Kim Woong-ki, Database Center for North Korean Human Rights, Seoul, December 17, 2009.

28. Author interview with Koo Byoung-sam, Ministry of Unification, Seoul, December 16, 2009. Williams and Mobrand (2010, 529-530) argue that "almost all media attention [to the abduction issue] has come from conservative media groups" and suggest that this has been met by "silence from the left."

29. AFU was also reportedly involved in this petitioning. Arrington, personal communication.

30. Korea Herald editorial cited by Arrington (2007, 12).

31. Author interview with Lee Keum-soon, Korea Institute for National Unification, Seoul, December 16, 2009.

32. Author interview with Choi Sung-yong, Abductees' Family Union, Seoul, December 21, 2009.

33. Ibid. See also Williams and Mobrand (2010, 514).

34. Ibid.

35. According to author interview with Do Hee-yoon, Citizens' Commission for Human Rights and North Korean Abductees, Seoul, December 15, 2009.

36. Ibid.

37. Author interview with Choe Chang-woo, Anti-Corruption and Civil Rights Commission, Seoul, December 18, 2009.

38. Author interview with Kim Woong-ki, Database Center for North Korean Human Rights, Seoul, December 17, 2009.

39. Author interview with Lee Keum-soon, Korea Institute for National Unification, Seoul, December 16, 2009.

40. In an interview (Seoul, December 17, 2009), Ms. Lee claimed that part of the inefficacy of the abductee groups is related to the influence of "procommunist groups" vis-à-vis the Kim and Roh administrations.

41. There have been on again-off again "family reunions," most recently in September 2009, when ninety-seven southerners went to Mt. Kumgang to meet 229 separated family members living in the North.

42. Author interview with Bae Youn-soo, Ministry of Unification, Seoul, December 18, 2009.

43. Author interview with Koo Byoung-sam, Ministry of Unification, Seoul, December 16, 2009. 
44. Ibid.

45. Author interview with Lee Keum-soon, Korea Institute for National Unification, Seoul, December 16, 2009.

46. Author interview with Kim Woong-ki, Database Center for North Korean Human Rights, Seoul, December 17, 2009. A Ministry of Unification official disagrees, insisting that there was evidence that "some abductees were spies." Author interview with Bae Youn-soo, Ministry of Unification, Seoul, December 18, 2009.

47. The interior quote is from a Korean language source.

48. Author interview with Do Hee-yoon, Citizens' Commission for Human Rights and North Korean Abductees, Seoul, December 15, 2009.

49. EAI seminar discussion, December 17, 2009.

50. Author interview with Koo Byoung-sam, Ministry of Unification, Seoul, December 16, 2009.

51. Officials report that "conflict among them is quite serious" and debilitating. In one case, the police were summoned to break up a fight between abductee group representatives who had been invited to discuss national policy. Do Hee-yoon, head of the Citizens' Commission for Human Rights and North Korean Abductees, claims to be coordinating twenty-five groups. Author interview with Do Hee-yoon, Seoul, December 15, 2009. The quote about conflict is from Lee Keum-soon, a senior official at the Korean Institute for National Unification. She reports calling the police to remove a member of the Abductee Family Union, the largest abductee group, from a meeting in 2007. Author interview, Seoul, December 16, 2009.

52. Worried that these appointments might be interpreted as an act of co-optation by the government, Investigation Commission chairman Araki Kazuhiro took pains to point out that this represented the "integration of the government commission, not the integration into the government commission."

\section{References}

Abe, Shinzo. 2006. Utsukushii Kuni E [Toward a beautiful country]. Tokyo: Bungei Shunju.

Arrington, Celeste. 2007. "Interest Group Influence in Policymaking Processes: Comparing the Abductions Issue and North Korea Policy in Japan and South Korea." Paper prepared for delivery at the annual meeting of the American Political Science Association, August 30-September 2.

Beal, Tim. 2005. "Multilayered Confrontation in East Asia: North Korea-Japan." Asian Affairs 36, 3: 339-360.

Center for North Korean Human Rights Studies, Korea Institute for National Unification, ed. 2009. White Paper on Human Rights in North Korea, 2009. Seoul: Korea Institute for National Unification.

Colley, Linda. 2002. Captives. New York: Pantheon.

Cumings, Bruce. 2007. "Why Memory Lingers in East Asia." Current History 106, 701 (September): 257-262. 
Cyranoski, David. 2005. "DNA Is Burning Issue as Japan and Korea Clash over Kidnappings." Nature 433 (February 3): 445.

Faludi, Susan. 2007. The Terror Dream: Fear and Fantasy in Post-9/11 America. New York: Metropolitan Books.

Finnegan, Michael. 2009. Managing Unmet Expectations in the U.S.-Japan Alliance. NBR Special Report. Seattle: National Bureau of Asian Reseach, November.

Funabashi, Yoichi. 2007. The Peninsula Question: A Chronicle of the Second Korean Nuclear Crisis. Washington, DC: Brookings Institution.

Gourevitch, Peter A. 1986. Politics in Hard Times: Comparative Responses to International Economic Crises. Ithaca: Cornell University Press.

Grant, Bruce. 2009. The Captive and the Gift: Cultural Histories of Sovereignty in Russia and the Caucasus. Ithaca: Cornell University Press.

Ha, Shin-gi. 2008. Tokyo Shogen: Kita Bijinesu, Ura Gaiko [Tokyo testimony: "North" business and secret diplomacy]. Tokyo: Kodansha.

Hasuike, Toru. 2006. Dakkan [Recapture]. Tokyo: Shinchosha.

-2009. Rachi: Sayu no Kakine wo Koeta Tatakai E [Abduction: Toward a struggle beyond left and right]. Kyoto: Kamogawa Shuppan.

Hughes, Christopher W. 1999. Japan's Economic Power and Security: Japan and North Korea. London: Routledge.

International Crisis Group (ICG), ed. 2005. "Japan and North Korea: Bones of Contention.” Asia Report No. 100, June 27. Seoul/Brussels: ICG.

Johnston, Eric. 2004. "The North Korean Abduction Issue and Its Effect on Japanese Domestic Politics.” Japan Policy Research Institute (JPRI) Working Paper No. 101, June. San Francisco: JPRI.

Katzenstein, Peter J. 1977. "Introduction: Domestic and International Forces and Strategies of Foreign Economic Policy." International Organization 31, 4: 587-606.

Kim, Hong Nack, and Jack L. Hammersmith. 2008. "Japanese-North Korean Relations After the Second Pyongyang Summit of 2004." North Korean Review 4, 1: 74-90.

Kim, Myungho. 2006. "Junjaeng Napbukjaui Napbukdonggi Bunsuke Gwanhan Siljeungjuk Yeongu" [Analysis of abductions to North Korea during the Korean War]. Jungchaekbunsukpyunggahakhuebo (September): 113-138.

Kitachosen ni Ratchi Sareta Kazoku ni yoru Renrakukai, ed. 2003. Kazoku [The families]. Tokyo: Kobunsha.

Korea Institute for National Unification, ed. 2005. "White Paper on Human Rights in North Korea, 2005." Seoul: Center for North Korean Human Rights Studies.

_ 2009. "White Paper on Human Rights in North Korea, 2009." Seoul: Center for North Korean Human Rights Studies.

Madsen, Robert, and Richard J. Samuels. 2010. "Japan, LLP." The National Interest 107 (May-June): 48-56.

McCormack, Gavan. 2002. "North Korea in the Vice." New Left Review 18 (November-December). 
McCormack, Gavan, and Wada Haruki. 2006. "The Strange Record of Fifteen Years of Japan-North Korea Negotiations." Japan Focus. Available at http://japanfocus.org/_Gavan_McCormack_and_Wada_Haruki-The _Strange_Record_of_15_Years_of_Japan_North_Korea_Negotiations.

McNeill, David, and Andreas Hippin. 2003. "Has Rightwing Highjacked Abductee Issue?" Japan Times, April 15.

Miller, Nathan. 1997. The US Navy: A History. Annapolis, MD: Naval Institute Press.

Ministry of Unification. 2005. "White Paper on Korean Unification." Seoul: Ministry of Unification.

Morris-Suzuki, Tessa. 2009. "The Forgotten Japanese in North Korea: Beyond the Politics of Abduction." Asia-Pacific Journal 43, 2 (October):1-19.

Olson, Mancur. 1965. The Logic of Collective Action: Public Goods and the Theory of Groups. Cambridge: Harvard University Press.

Samuels, Richard J. 2003. Machiavelli's Children: Leaders and Their Legacies in Italy and Japan. Ithaca: Cornell University Press.

2007. Securing Japan: Tokyo's Grand Strategy and the Future of East Asia. Ithaca: Cornell University Press.

Sato, Katsumi. 2004. Kitachosen ni yoru Ratchi wo Kangaeru (Thoughts on the abductees in North Korea). Tokyo: Meiseisha.

Shun, Yul. 2002. "Napbukja Munje Haegyulbangan Yeongu" (A study of those kidnapped to North Korea). Sahuegwahaknonchong 18, 1: 153-175.

Slotkin, Richard. 1973. Regeneration Through Violence: The Mythology of the American Frontier, 1600-1860. Middletown, CT: Wesleyan University Press.

Snyder, Jack. 1991. Myths of Empire: Domestic Politics and International Ambition. Ithaca: Cornell University Press.

Steinhoff, Patricia G. 2008. "Political Ties of Visible (Right) and Invisible (Left) Social Movements in Contemporary Japan." Paper presented to the annual meeting of the Association of Asian Studies, Atlanta, April.

Tanaka, Hitoshi. 2009. Gaiko no Chikara [The power of diplomacy]. Tokyo: Nikkei.

Tsuji, Kiyoaki. 1984. Public Administration in Japan. Tokyo: University of Tokyo Press.

Williams, Brad, and Erik Mobrand. 2010. "Explaining Divergent Responses to the North Korean Abductions Issue in Japan and South Korea." Journal of Asian Studies 69, 2: 507-536.

Wilson, James Q. 1980. The Politics of Regulation. New York: Basic Books.

Yokota, Sakie. 2009. North Korea Kidnapped My Daughter: A Memoir. New York: Vertical. 


\section{We help Asia speak to the world and the world speak to Asia.}

Can you afford not to read Global Asia?
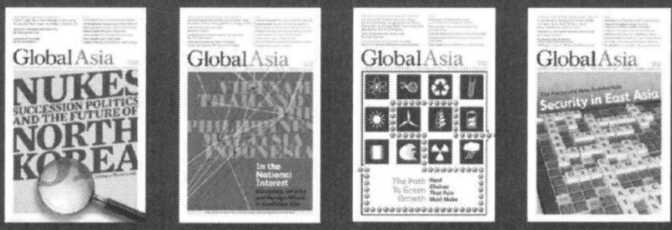

To find out more, go to www.globalasia.org 